\title{
The Revision of the Constitution in the PRC
}

A great leap forward or a symbolic gesture?

\section{Chen Jianfu}

\section{OpenEdition}

\section{Journals}

Édition électronique

URL : http://journals.openedition.org/chinaperspectives/2922

DOI : 10.4000/chinaperspectives.2922

ISSN : 1996-4617

Éditeur

Centre d'étude français sur la Chine contemporaine

Édition imprimée

Date de publication : 1 mai 2004

ISSN : 2070-3449

\section{Référence électronique}

Chen Jianfu, «The Revision of the Constitution in the PRC », China Perspectives [En ligne], 53 | MayJune 2004, mis en ligne le 29 décembre 2008, consulté le 28 octobre 2019. URL : http:// journals.openedition.org/chinaperspectives/2922 ; DOI : 10.4000/chinaperspectives.2922

Ce document a été généré automatiquement le 28 octobre 2019.

(c) All rights reserved 


\section{The Revision of the Constitution in the PRC}

A great leap forward or a symbolic gesture?

Chen Jianfu

1 At the Second Plenary Session of the Tenth National People's Congress (March 5th-14th 2004), the Constitution of the PRC underwent yet another revision ${ }^{1}$. As usual, the revision of the Constitution is praised by the Chinese media and deputies to the Congress as "having deep and far reaching significance", etc. ${ }^{2}$. This periodical revision of the Constitution-four times $(1988,1993,1999$ and 2004) since its adoption in 1982 makes the Chinese Constitution one of the most frequently revised, if not the most frequently revised, constitutions in the world. This is however not to say that the revision is merely a political exercise. Seen as the "mother of all laws" ${ }^{4}$ in China, the Chinese Constitution sets parameters for legal developments, and any breakthrough in the setting of such parameters will be significant for the development of constitutionalism. This paper examines the most recent constitutional amendments adopted on March 14th 2004 by the National People's Congress (NPC) ${ }^{5}$, which took effect on the same day. In order to give a full picture, a brief review of previous revisions is provided. It is argued that, while the present constitutional amendment will have little immediate impact on society or the economy, it offers potential for future legal development and human rights protection. Further, if the amendments adopted in 1988, 1993 and 1999 reflect the continuing conceptual evolution of socialism in China and the 1999 amendments evidence a consensus among the Communist Party of China (CPC) leadership on the nature of "socialism with Chinese characteristics" as well as providing further legal protection to "capitalist" economic practices ${ }^{6}$, the present revision indicates a certain distinct confidence of the Chinese leadership in pursuing its own version of socialism. It is however also argued that, as it was with the 1999 revision, more important and fundamental problems in the present Constitution are yet to be addressed, hopefully in the not too distant future.

The development of the 1982 Constitution 
2 The 1982 Constitution is essentially a Dengist constitution, reflecting Deng Xiaoping's ideas for modernising China, i.e., social stability, economic development and opening to the outside. It is also a result of the constant, and sometimes painful, search for China's own version of socialism ${ }^{7}$. It made its tentative move towards liberalisation, politically and economically, while insisting on firm control by the Party. Thus, the Preamble both upholds the so-called "Four Fundamental Principles" 8 and emphasises the construction of socialist modernisation as a fundamental national task. Article 18 of the Constitution formally provides a constitutional basis for foreign investment and its protection in China. Article 11 of the Constitution allows the development, within the limits prescribed by law, of an individual economy as a complement to the socialist economy. Article 10, for the first time in the PRC's constitution, defines the ownership of land in China. Although hailed as "the best since the founding of the PRC", the 1982 Constitution was soon amended, in April 1988, to legitimise the existence of the rapidly developing private economy as well as to provide a constitutional basis for the commercial transfer of land use rights, both of which were the results of economic reform and prerequisites for further economic development.

3 Further ideologically significant revision was necessitated by the adoption by the Party at its Fourteenth Congress of the notion of a "socialist market economy" in 1992. So not long after the Central Committee of the CPC formally submitted its "Suggestions on Amending Certain Contents of the Constitution" the NPC dutifully adopted the suggestions and translated the new Party policy into law in March $1993^{10}$. As a result of the revision, the term "socialist market economy" then replaced that of "planned economy". The terms "state-run (guoying) economy" and "state-run enterprises" replaced by "state-owned (guoyou) economy" and "state-owned enterprises" respectively. Similarly, provisions on state planning were removed and in their place were put provisions that require the state to strengthen economic legislation and macro-economic control. On the whole, the 1993 amendment provides flexibility, though not specific direction, for future development. The Fifteenth Party Congress in 1997 laid down certain political foundations for post-Deng China ${ }^{11}$, which adopted a policy to continue the reform policy launched by Deng Xiaoping in 1979 and to incorporate a Dengist version of socialism into the constitution ${ }^{12}$.Once again, efforts took place to transform the Party policy into constitutional provisions through constitutional revision. The revision was undertaken by a Revision Group of the Central Committee of the Party, headed by Li Peng. Since its first draft, issued on December 5th 1998 for internal Party discussion, the drafting work went swiftly. By January 22nd 1999, a formal proposal had already been made by the Party to the Standing Committee for consideration and adoption ${ }^{13}$. The formal adoption at the Second Session of the Ninth NPC was a formality; the proposal was adopted word for word ${ }^{14}$.The six amendments in 1999 fall into three categories: further supplementation to the Four Fundamental Principles, a Chinese version of the "Rule of Law", and a politicoeconomic version of "socialism with Chinese characteristics" ${ }^{15}$. On the whole, the 1999 revision of the Constitution was essentially designed to carry out the conversion of the adopted ideology of the Fifteenth Party Congress of 1997 into the form of fundamental state law, that is, to convert the will of the Party into that of the state. The revision reflects the Party's determination to continue the reforms and opening-up and to administer the country according to law. Examined from a development perspective, such revision indicates the then understanding of the notion of socialism with Chinese characteristics among the Party leadership. 
4 The First Plenary Session of the Sixteenth Party Congress (2002) began the change-over of Party leadership, which continued until the First Plenary Session of the Tenth National People's Congress in 2003. These congresses saw the partial handover of leadership power from Jiang Zemin to $\mathrm{Hu} \mathrm{Jintao}^{16}$. So, the Sixteenth Party Congress was to sum up the Party's experience (or to record its achievements) in the previous five years and to set out a policy direction for the new leadership. Not surprisingly, the policy "spirit" as adopted by the Sixteenth Party Congress would need to be incorporated into the Constitution; hence a new round of constitutional revision.As early as on March 27th 2003, a Constitutional Revision Group, headed by Wu Bangguo (the new Chairman of the Standing Committee of the NPC) and under the direct leadership of the Standing Committee of the Politburo of the Party, was established. At the same time, the principles for the revision were also set down by the Standing Committee of the Politburo ${ }^{17}$. Official consultation was swiftly conducted in the next several months within limited circles of authorities and personnel, such as of provincial leaders, leaders of the democratic parties, and selected groups of local leaders and prominent scholars ${ }^{18}$. The draft Suggestion on Amending Certain Contents of the Constitution was soon taking shape by August 2003. It is at this time that the on-going revision was first officially reported ${ }^{19}$. It should be pointed out that even though this was the first formal announcement of the on-going revision of the Constitution, there was no mention of such a Group, even though it was said that the plenary session would discuss the proposals for constitutional reform ${ }^{20}$. As was the previous practice, the recommendations were dutifully and faithfully adopted by the NPC, making itself once again a rubber stamp of the Party. Sadly, this practice is patently undemocratic: If the people have no right to participate in such fundamentally important political matters, it is perhaps unrealistic, if not insulting, to tell the people that they enjoy democracy and the rule of law.Even though the on-going revision was not officially reported until August 2003, the Chinese media began to break the news unofficially around June $2003^{21}$. It was clear that Chinese scholars were consulted at a rather early stage, and certainly no later than June 2003. Not surprisingly, academics began to express a wide range of views and opinions, suggesting far reaching revisions to the Constitution ${ }^{22}$, and academic symposiums devoted to the revision were also organised, the most notable convened in Qingdao $\mathrm{City}^{23}$, and in Shanghai ${ }^{24}$, both in June 2003 and both of which were attended by prominent scholars consulted by the Politburo on the revision, such as Professors Jiang Ping and Wu Jinlian. However, enthusiasm among academics was quickly dampened. A secret instruction was soon issued by the Party to stop all conferences and publication of academic papers on constitutional reform, and leading economists and legal scholars actively involved in presenting their views were reported to have been harassed by the security forces ${ }^{25}$. Thus, contrary to the assertion by the Chinese authorities that the revision of the constitution was carried out on a democratic basis with wide consultation ${ }^{26}$, consultation was only conducted within the strictly limited circles of the authorities and the elite.

5 Nevertheless, the drafting went swiftly. By mid-October 2003, the Suggestions on Amending Certain Contents of the Constitution had been adopted by the Third Session of the Central Committee of the Sixteenth Party Congress, which also decided to pass the Suggestions to the Standing Committee of the NPC to be converted into a constitutional amendment bill in accordance with the constitutional procedures. As usual, the Standing Committee of the NPC dutifully did so at its Sixth Meeting of the Tenth NPC held during December 22nd-27th 2003. Also on December 22nd 2003, the 
Suggestions on Amending Certain Contents of the Constitution were, for the first time, published in full in the Chinese media. Theoretically, the Amendment Bill finally adopted by the full NPC on March 14th 2004 was no longer a Party document, but a formal legislative bill, except that the Bill was a verbatim copy of the Suggestions. As such, the revision started in late March 2003 and completed in mid-October of the same year was another world record.

Major revisions

6 Similar to the 1999 revision, the present revision is designed to incorporate policy decisions made at the Sixteenth Party Congress in 2002, including the adoption of the "Three Represents" idea, along with the "Four Fundamental Principles" and Deng Xiaoping's Theory, as guiding principles of the Party. It is meant to be a partial, not comprehensive, revision ${ }^{27}$. It was expressly decided that only the matters that must be regulated by the Constitution and only the provisions that must be revised immediately would be dealt with by the revision. Other matters, though desirable for revision, would be clarified later by constitutional interpretations, rather than by the present revision. In other words, the present revision is little more than an implementation of the Party policies as adopted at the Sixteenth Party Congress in 2002.The various amendments fall into five categories: the adoption of a new guiding principle for the Constitution, an explicit recognition of human rights, further protection for private property, a more civilian-type approach to a state of emergency, and some technical revisions.

A personal stamp?

7 The Chinese Constitution, like many others, is ideology-ridden, but none is more heavily so than its Preamble. What makes the Chinese Constitution stand out so strikingly is the constantly changing perception of socialism and of the guiding principles for building socialism with Chinese characteristics. Thus, when Deng Xiaoping came to power, he managed to repudiate the radical ideas preached during the Cultural Revolution, but retained the status of secular god of Mao Zedong. He thus incorporated the Four Fundamental Principles into the Constitution. When Deng Xiaoping handed power to Jiang Zemin, the latter soon elevated Deng's idea of building socialism and modernising China into a constitutional guiding principle in the name of Deng Xiaoping Theory ${ }^{28}$. Now Jiang is retiring he wants to put a personal stamp on the Constitution too. In the last few years he has been busy promoting his awkwardlyworded "Three Represents" as "new thinking". As such, that each constitutional revision coincides with the five-year term of the Party Congress and the NPC reflects in effect the changes in Party leadership. Jiang Zemin began to talk about the "new thinking" of the Three Represents in February 2000 in a piecemeal fashion ${ }^{29}$. However, from 2000 through to the end of 2002, he managed to wage a major political campaign, but most importantly, he managed to have the Party Constitution changed at the Sixteenth Party Congress in 2002. At this Congress, the phrase "Ruling the Country According to Law" was added to the Party Constitution ${ }^{30}$. To this effect, paragraph 12 of the Preamble of the revised Party Constitution now states: "The Communist Party of China leads the people in promoting socialist democracy and building socialist political civilisation. It keeps expanding socialist democracy, strengthens the socialist legal system, rules the country according to law, builds a socialist country ruled according to law, and consolidates the people's democratic dictatorship" ${ }^{31}$.The same revision of the Party Constitution also declares that "[t]he Communist Party of China leads the people in their efforts to build a spiritual as well as a material and political civilisation and to 
combine ruling the country according to law with ruling the country by virtue" ${ }^{32}$. In addition to upholding the Four Fundamental Principles and Deng Xiaoping Theory ${ }^{33}$, the revision also adds Jiang Zemin's Three Represents as important "Thought" which shall guide the actions of the Party ${ }^{34}$. The Three Represents means, according to the revised Party Constitution, that the Party represents the development trend of China's advanced productive forces, the orientation of China's advanced culture and the fundamental interests of the overwhelming majority of the Chinese people. In other words, the Party represents what are perceived by the Party as the "advanced" forces of society at a given time. The political rationale for this "new thinking" is then clear, that is, as an embodiment of the "advanced" forces, the Party could continue to maintain control of, legitimacy in, and relevance to the society. This having been done, it is not surprising that the first amendment for the new revision is to incorporate the changes in the Party Constitution into the State Constitution. Thus, the amended Constitution (para. 7 of the Preamble) now "enshrines" into the State Constitution the "important thinking of the Three Represents" as a national guiding ideology. At the same time, "promoting the co-ordinated development of a materialist, political and spiritual civilisation" is also added to paragraph 7 of the Preamble. The latter signals that the newly enshrined "Ruling the Country According to Law" will now formally be supplemented by "ruling the country by virtue", a phrase which attempts to re-enforce the role of the Party leadership as the bearer of correct ideology as well as combining law and morality in ruling the country. However, one must not read too much into these frequent changes/additions of political phrases, otherwise we may well fall into the trap of what a prominent Chinese legal scholar has termed "the tendency of ruling the country by slogans" ${ }^{35}$.

8 And awkward as it might be in its wording, the Three Represents as "new thinking" is not completely devoid of practical implications ${ }^{36}$. Indeed, that the Party must represent the development trend of China's advanced productive forces is nothing more than an ideologically coated phrase to say that capitalism is not inherently contradictory to communism. It is under this "new thinking" that the Party invites "capitalists" to join the Party, thus effectively telling the Chinese people that the Party does not only want capitalists as a new force (builders in the cause of socialist construction) in the United Front ${ }^{37}$, but also as a part of the Party. That is to say, "getting rich is not only glorious (being in the United Front) but also prestigious (being part of the Party)". Further, the added protection for private property may also be seen as a consequence of this "new thinking".

9 There is also a quiet change of wording in the Preamble of the Constitution in relation to the description of China as a socialist country. In the 1993 constitutional revision the following phrase was added to the Preamble, which reads "[o]ur country is in the primary stage of socialism. The basic task of the nation is to concentrate its efforts on socialist modernisation in accordance with the theory of building socialism with Chinese characteristics." That was an ingenious invention to justify "capitalist" practices in a socialist country ${ }^{38}$. In the 1999 constitutional revision, these two sentences were further changed to "[o]ur country will over a long period of time be in the primary stage of socialism. The basic task of the nation is to concentrate its efforts on socialist modernisation in pursuing the construction of socialism with Chinese characteristics." This then was to signal to the world that capitalism will be tolerated on a long-term basis and to declare that building socialism with Chinese characteristics was no longer a theory but a practice as well. The quiet change in the present revision 
from "in pursuing the construction of socialism with Chinese characteristics" into "along the road of Chinese-style socialism" thus indicates the confidence of the leadership that the Party and the state are no longer hesitating in their search for an original Chinese version of socialism ${ }^{39}$.

Towards an Age of Rights?

Perhaps the most important and striking revision is the declaration, without any qualification and without much debate and controversy as in the case of private property, that "[T] he state respects and protects human rights"

The term "human rights" has a rather bumpy history in the PRC. Although there have been many lively debates on issues commonly understood as human rights, the term was rarely applied as official language; instead, all Chinese constitutions have consistently used the term "citizen's rights", which implicitly rejects the universality of human rights and implied the class nature of such rights; that is, citizens may be differentiated according to their class backgrounds. It may also imply the exclusion of foreigners and stateless persons in China ${ }^{41}$. Ironically, the term "human rights" was only officially used after the June 4th Tiananmen Square incident in 1989, in particular after the State Council issued its white paper, Human Rights in China, in $1991^{42}$.

This declaration can have some significant practical implications. First, this unqualified declaration perhaps means that China has now finally come to accept universal human rights, rather than insisting on an "Asian" or "Chinese" conception of human rights. Secondly, also as a consequence of this unqualified declaration, the scope of human rights could be interpreted to include not only the fundamental rights as codified in Chapter Two of the Constitution but also those contained in, at least, the two International Covenants that China has signed ${ }^{43}$, such as the right to strike which was abolished during the making of the 1982 Constitution ${ }^{44}$. Thirdly, the insertion of this declaration in Article 33 bears some significant practical implications. Article 33 defines the nature of rights in China: that is, all citizens are equal before the law and citizens, while enjoying rights, must also perform the duties as prescribed by the Constitution and the law, the so-called "unity of rights and duties".

The use of the term "citizen's rights" instead of "human rights" is not without practical significance. Here, the provisions of Article 33 are not without some major problems: equality before the law apparently refers to equality in implementing laws, not in lawmaking ${ }^{45}$, and would only be enjoyed by citizens of the PRC ${ }^{46}$. The declaration on the respect for and protection of human rights could potentially allow the court to interpret "all citizens are equal before the law" to mean "all people are equal before the law"; otherwise the provisions in Article 33 would be inherently inconsistent. Finally, with calls from academics and officials to pay attention to the actual implementation of the Constitution ${ }^{47}$, Chinese courts can and should take protection of human rights as a major consideration in its adjudications, at least when the relevant Chinese law is not clear or is ambiguous on particular matters. Certainly we are not seeing the coming of age of rights in China as yet, as the various international human rights reports on China testify. However, this declaration may, as Xu Xianming, a jurist and a deputy to the NPC has rightly pointed out, ultimately bring about changes to the state's value system $^{48}$.

A bold approach to a fundamental ideological dilemma?

14 A central tenet of socialism is its insistence on public ownership and, thus there are serious difficulties in dealing with private property in a socialist constitution. An 
important attempt is made in the current revision to once again address the question of private property in the constitution, thus strengthening the constitutional protection of private property.

Initially, Article 11 of the 1982 Constitution defines the individual economy of urban and rural working people as a complement to the socialist public economy, and the lawful rights and interests of the individual economy are protected by the state. Article 13 protects the right of citizens to own lawfully earned income, savings, houses and other lawful property, as well as the right to inherit private property. Here, the individual economy of urban and rural working people refers to the economy in the form of Individual Industrial and Commercial Households and Rural Contracting Households (the so-called "Two Households") ${ }^{49}$. This was the only private economy allowed by the Chinese law at the time. The post-Mao economic reforms saw the emergence of private enterprise, defined as "a privately funded economic entity which employs at least eight persons" 50 . Article 11 of the Constitution was then amended in 1988 to "permit the private economy to exist and to develop within the limits prescribed by law" and defines such an economy as a complement to the socialist public economy. Here, the private economy refers to the economy in the form of private enterprises as defined by law.

The rapid development of the private economy ${ }^{51}$, again necessitated further elevation of the role of the non-public economy. Through the 1999 constitutional revision the individual and private economies were no longer defined as a complement to the socialist public economy; they were treated as "an important component of the country's socialist market economy" 52 . Further, the 1999 revision tried to treat the individual and private economies on an equal footing, whereas the previous provisions seemed to accord a different degree of state control over them ${ }^{53}$.

Because of the specific meaning of the individual and private economies and the continuing flourishing of the private sectors in different business forms and structures, such as sole proprietorship and partnerships, there is a clear need to accord constitutional protection to these new forms of the private economy, hence the insertion of the phrase "other non-public economy" into Article 11 through the present revision. Though the phrase is an ambiguous one, it is meant to embrace the various existing and emerging forms of private business, including foreign investment in China. In addition to providing protection, the revision further adds that the state will also provide encouragement and support to the development of the non-public economy. By doing so, the private sectors final achieve equal status with their public counterparts in most economic activities ${ }^{54}$.The controversial part of the revision concerns the revision of Article 13. Article 13 does provide protection to lawful income, houses and other private property and the right to inheritance. There has long been uncertainty about Article 13. First, the listing of lawful income, wages, houses, etc., came from the socialist distinction of means of production and means for livelihood ${ }^{55}$, with only the latter being allowed to be owned privately. Secondly, public property is declared sacred and inviolable by the Constitution (Article 12), while the state only offers protection for limited private property. This implicitly indicates a different degree of protection to the two types of property. Further, Article 13 refers to ownership rights to property (suoyouquan) instead of the more universally understood term of property rights (caichanquan). The revision thus intends to do away with one of the last remnants of the influence of Soviet law. 

inviolable. Further, if private property is expropriated or taken over for state use, compensation must be paid by the state under the revised Constitution. Similarly, as land-use rights have been commercialised, compensation for expropriation or taking over for use by the state is also guaranteed by the revised Constitution ${ }^{56}$, As such one can say quite comfortably that for most practical purposes equal protection is now provided for both public and private property. This should now clear away one of the most difficult aspects of enacting a civil code in China: how to deal with the differentiated treatment of public and private property under a unified notion of property rights ${ }^{57}$.

There is now better protection for private propriety

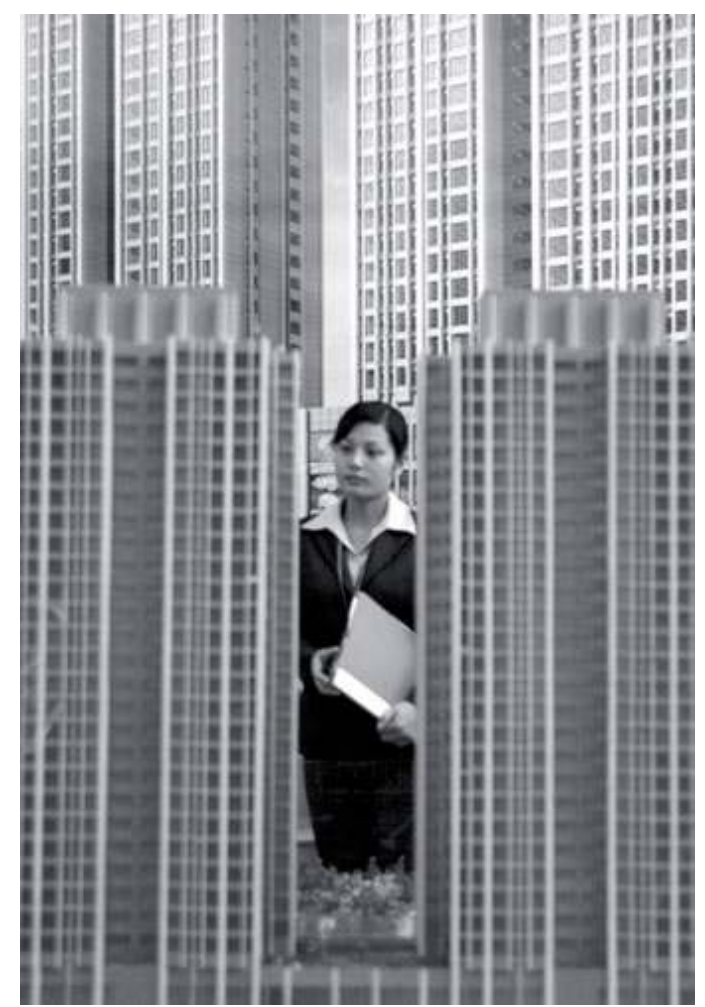

(c) Imaginechina

As mentioned earlier, this revision has been controversial. However, the controversy is not about the protection for private property per se, it is the concern about the legalisation of illegally acquired property, such as that acquired through corruption, the embezzlement of public property by various means, and other illegal means. Thus, the use of the adjective "lawful" in front of private property is not redundant; it is used to address the fear that illegally acquired property might become untouchable.

Being a socialist country and having provided constitutional protection to private property, China faces an obvious question, that of social justice, or the establishment of a minimum social safety net in the face of the increasingly widening gap between the rich and poor. This the Chinese government in fact began to address several years ago $^{58}$. The present revision now makes it a constitutional obligation of the state to establish a social security system appropriate to the level of national economic development ${ }^{59}$. Once again, it is a positive development that should provide the poor 
with a constitutional claim, at least theoretically, or a moral claim, against the government should the government fail to deliver a minimum social safety net.

A civilian approach to a state of emergency

21 The original Constitution provided the Standing Committee of the NPC with the power to declare the imposition of martial law (jieyan) (to be proclaimed by the President of the PRC) throughout the country or in particular provinces, autonomous regions or municipalities directly under the Central Government, and gave the State Council the power to impose the order in parts of provinces, autonomous regions and municipalities directly under the Central Government ${ }^{60}$. This the State Council did in Tibet and in Peking in 1989. However, the circumstances under which martial law may be declared are only vaguely defined by Article 2 of the Martial Law of the $\mathrm{PRC}^{61}$, which provides for the imposition of martial law in a state of emergency in which social turmoil (dongluan), a violent upheaval (baoluan) or serious disturbance (yanzhong saoluan) is occurring and where extraordinary measures must be taken to maintain social order and protect life and property. Under this definition and through the experiences in Tibet and Peking in 1989, martial law is widely perceived as immediately and directly invoking a military-style solution to civilian unrest that might not warrant any violent solution, thus causing the unnecessary involvement of the army ${ }^{62}$. The revision now replaces the power to order martial law with the power to declare a state of emergency (jinji zhuangkuang). While this revision clearly widens the scope within which restrictions may be imposed through a declaration, such as in cases of the SARS epidemic and other natural disasters (such as floods) ${ }^{63}$, it also signals the willingness of the state authorities to explore civilian solutions, such as the primary use of civilian police to deal with civil unrest and other emergency situations, leaving the military solution as the last resort. Considering the tragedies in Tibet, Peking and several other cities in 1989, the revision is both positive and potentially life-saving. Since the Martial Law of the PRC was enacted in 1996, the revision of the Constitution would now require that the law be revised. Since the Constitution provides few procedures or criteria for declaring a state of emergency, it is hoped that a new law on states of emergency will clearly set out all these details ${ }^{64}$, hence providing further protection to the peaceful exercise of some fundamental human rights, such as the right to assembly and to demonstration.

Other technical revisions

Other revisions are largely non-controversial and technical in nature. With the return of sovereignty over Hong Kong and Macao to the PRC, the representation of these regions in the NPC is now guaranteed by the Constitution ${ }^{65}$. Heads of state in all countries routinely conduct state affairs, such as paying or hosting state visits, so the President of the PRC, being the head of state, is now provided with the power to conduct such affairs ${ }^{66}$. Since the term of the NPC and provincial people's congresses is five years, it is only appropriate to grant people's congresses at the township level the same term of office ${ }^{67}$. By doing so, it implicitly elevates the status of people's congresses at the township level and, perhaps, may also afford some protection to elected people's representatives at this level through the extension of their tenure of office. Finally, the national anthem, the March of the Volunteers ${ }^{68}$, has been sung by the Chinese people ever since the founding of the PRC, and was formally declared the national anthem by the NPC in 1982 so it is again appropriate to give it constitutional status ${ }^{69}$. Further, the incorporation of the national anthem in the state constitution is to immortalise the 
revolutionary spirit as contained in the national anthem and, surely, makes any future change of the national anthem difficult.

A cautious or conservative approach?

Other than the imposition of a Party ideology, that of the Three Represents, upon the people $^{70}$, the present revision of the Constitution is largely positive and should be welcomed as such. Clearly, the future impact of some of the revisions is potentially farreaching with significant practical ramifications. The problem is therefore not principally with the contents of the revisions, but with the frequent changes of a fundamental law and the issues that are not addressed.

True, the Constitution is conceived of as a document that affirms the achievements of the struggles of the Chinese people and is intended only to contain the "very fundamental and necessary" provisions that can be decided at the present time ${ }^{71}$. It is also a document that defines the basic system and basic tasks of the nation in a legal form. It is a set of general rules and serves the state as a fundamental charter of organisation $^{72}$. As such a political document, one would expect it to be revised from time to time in accordance with the perception of the current leadership of the CPC about the present and the future ${ }^{73}$. However, a revision of the fundamental charter of a nation every five years is, by any criteria, far too frequent, and likely to undermine, rather than to enhance, the authority of the Constitution.

On the other hand, the present Constitution is not one that is already "perfect" and needing no further revision. Indeed, it is a document riddled with many fundamental flaws. The problem with the current revision is, therefore, not what has been revised, but what has not been addressed. Thus the question is, what are the problems that require urgent action. The list would be very long ${ }^{74}$, however, chief among these problems are the lack of implementation procedures and a meaningful mechanism of checks and balances. The former may be achieved through other basic laws but the latter has to be dealt with in the Constitution ${ }^{75}$.

There are also some very pressing practical reasons that the Constitution requires more extensive, if not fundamental, reforms. In a widely publicised case, now often referred to as the "Seeds Case", a judge in a local court (Luoyang Intermediate Court in Henan Province) invalidated a local regulation on the basis of its being in conflict with the national Seeds Law. This decision quickly attracted intervention from the Standing Committee of the Henan People's Congress. The intervention was extraordinary in that the Standing Committee demanded the rectification of the decision and severe punishment of the judges even before an appeal had been dealt with by a higher court $^{76}$. This simple contractual dispute and especially the subsequent intervention by the local legislature reveals a great deal (though not all) of the systemic problems in the Chinese legal system concerning implementation of law: the existence of a hierarchy of law but the almost total absence of mechanisms and procedures for dealing with conflict of laws in the hierarchy, the ambiguous constitutional and institutional division of powers, the tension between judicial independence and accountability, the focus on substantive justice at the price of due process, the conflict of local and national interests, and, of course, the constant power struggles between and among institutions and personnel. Added to these problems, though not related to the present case, are the widely reported judicial corruption and incompetence, sensitivity to suggestions for political reform, and the all-powerful yet often invisible 
Party and government intervention in judicial activities. Clearly, some of these issues need to be addressed through the Constitution.

In another case, which is widely reported as the first instance where constitutional rights were directly enforced by a court, in mid-2001 the Supreme People's Court gave a clear and positive reply in relation to a request from Shandong High Court concerning whether the right to education as contained in the Constitution could be directly enforced and, if so, used as a legal basis for damages ${ }^{77}$. While this is a very positive development in constitutional law in China, the case raised many practical questions regarding whether the Supreme People's Court has a proper constitutional power to undertake such implementation through interpretation and, if so, whether there are procedures that the Court must follow ${ }^{78}$.

Finally, after some twenty years of promulgation of the Constitution, the knowledge of the Constitution among the Chinese people, as least in terms of knowing of its existence, is high and their expectation of the actual implementation of the constitution must not be disregarded in constitutional reforms. In a survey conducted by a group of Suzhou University scholars ${ }^{79}$, it was revealed that $96.9 \%$ of the people surveyed knew the existence of the Constitution, $66.14 \%$ of the people believed that a constitution was to impose constraints on government and to provide protection for the rights of citizens, $66.53 \%$ of people believed that the main cause for corruption was the lack of checks and balances; and $53.65 \%$ of them did not believe that the Constitution had any major real effect. In this context, the several appeals made by prominent scholars to the Standing Committee for constitutional review in relation to some controversial cases perhaps represent more than an elitist attempt to achieve political reform ${ }^{80}$, and show that the true aspiration of the people is for the Constitution to have some real effect on their lives.

The minimalist approach to the revisions of the Constitution, not just the present but also the earlier revisions in 1988, 1993 and 1999, may reflect a cautious attitude towards changes in the Constitution, since such caution has been rightly called for by some jurists in China ${ }^{81}$. On the other hand, an approach which is minimalist, yet applied frequently, may in truth represent a conservative attitude towards, or simply a lack of confidence and courage in undertaking, any fundamental political and constitutional reform. However, Party leadership and state authorities are no longer the only driving forces for reform in contemporary China; ordinary people ${ }^{82}$ and, especially, intellectuals ${ }^{83}$ are important and active agents that often push the constitutional parameters for further political, legal and economic reforms. In this context, there are reasons to be cautiously optimistic about the future of rule of law and constitutionalism in China. 
A Comparative Table of Constitutional Amendments since 1982
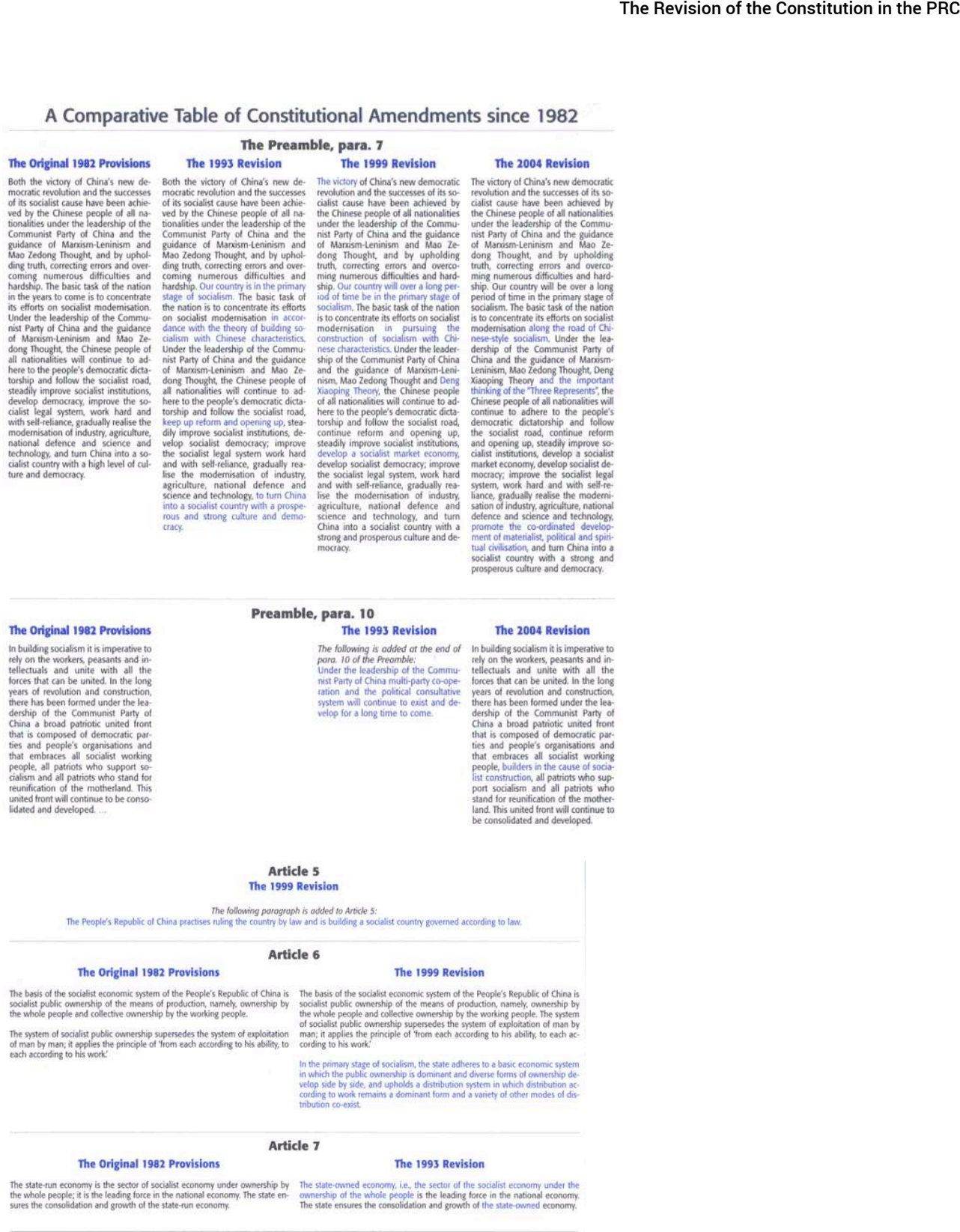

Preamble, para. 10

The 1993 Revision

The 2004 Revision

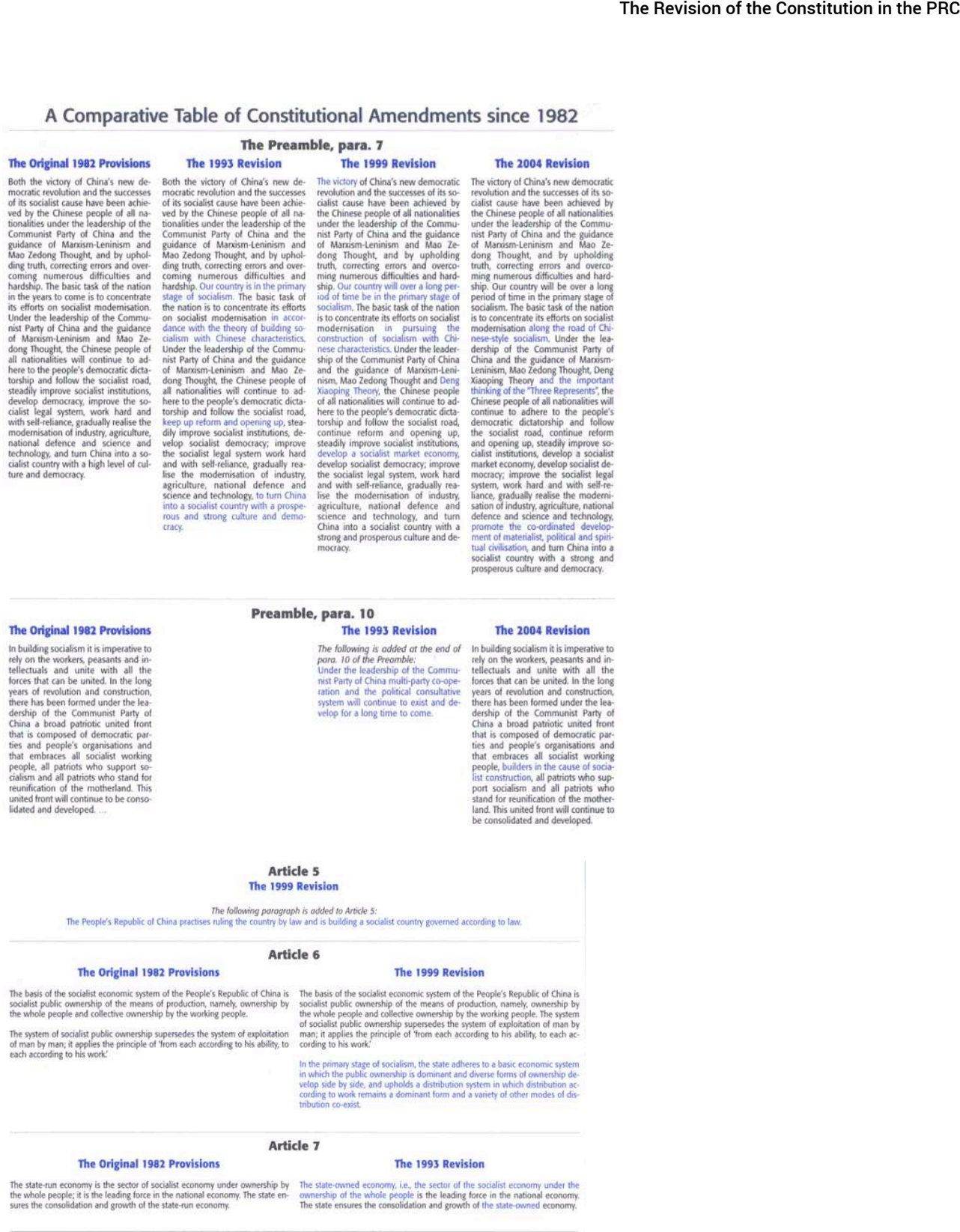

buiding socialism $\mathrm{i}$ is imperative to

rystem will continue to exist and det

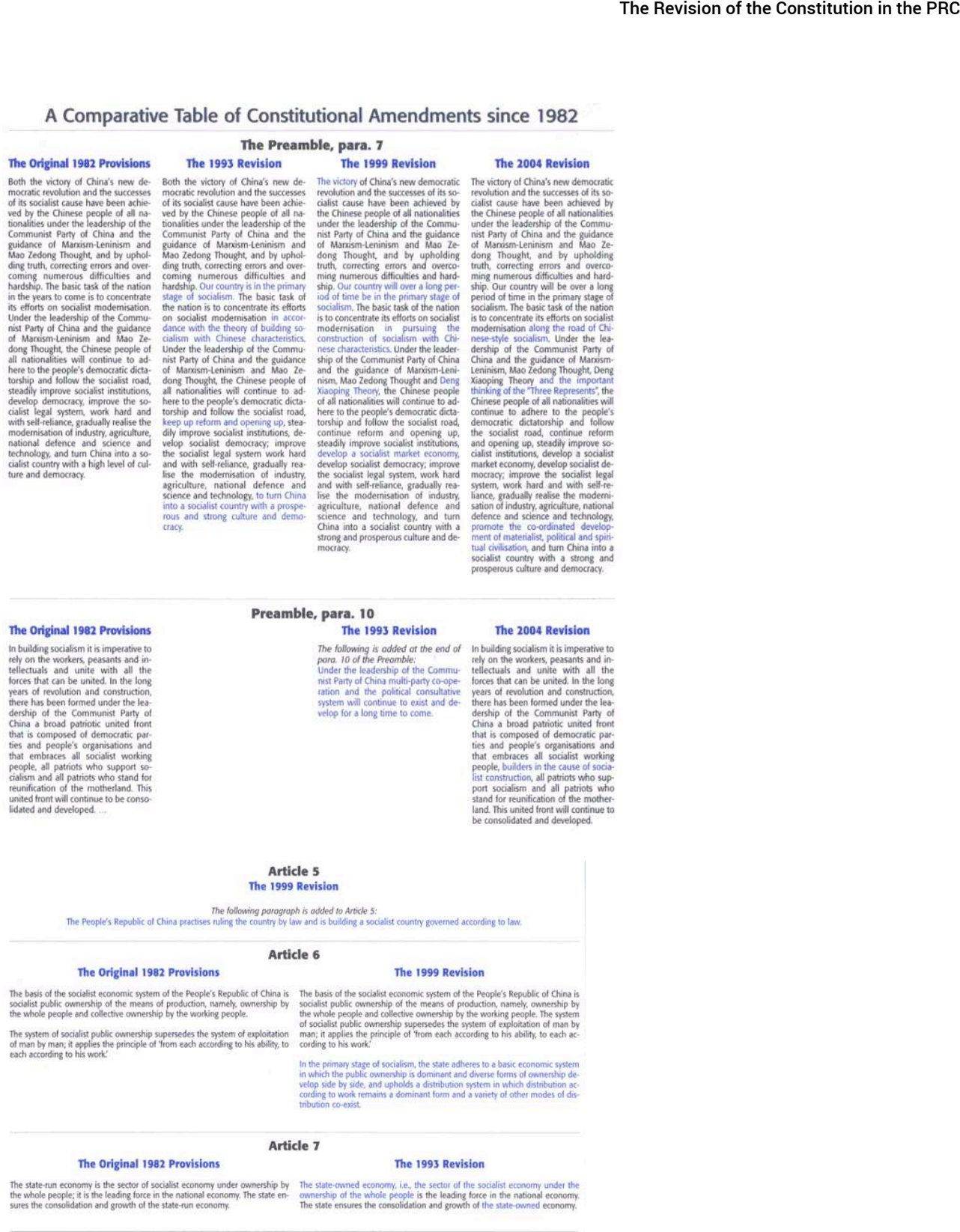

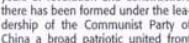

that is composed of democrastic part-

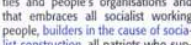

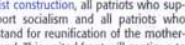

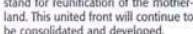

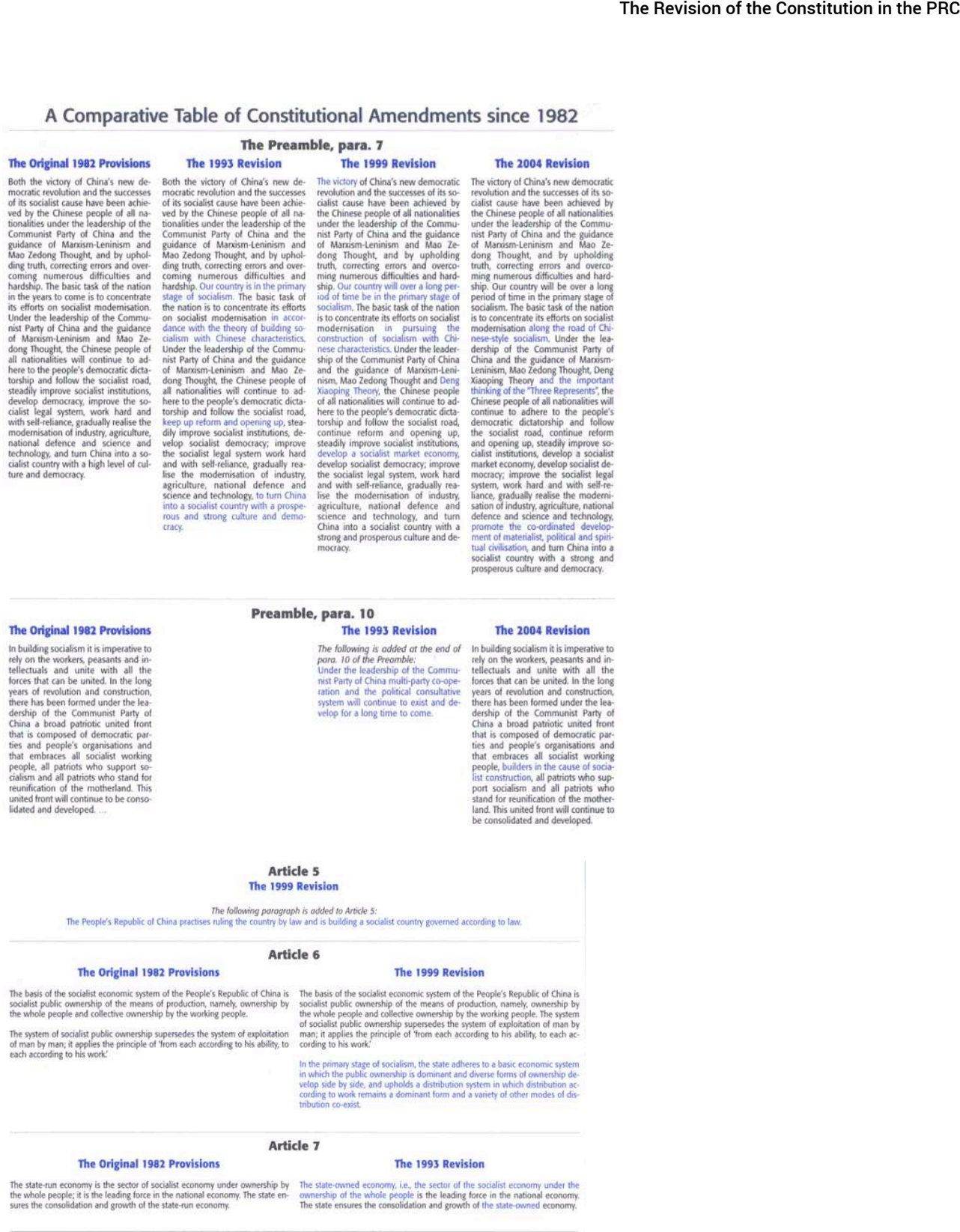

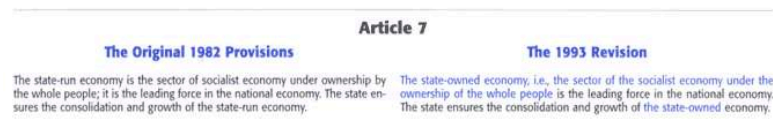

The 1999 Revision
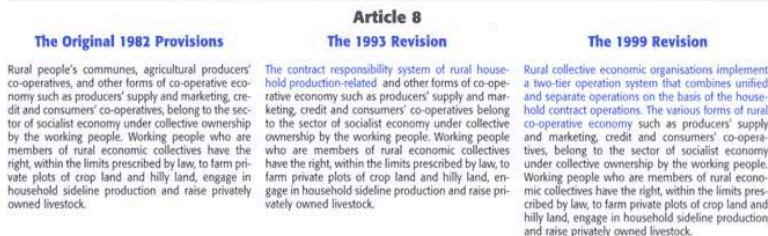

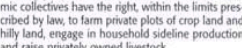

Article 10, para. 3

The Original 1982 Provisions

The 2004 Revision

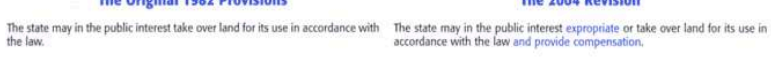

Article 10, para. 4

The Original 1982 Provisions

The 1988 Revision

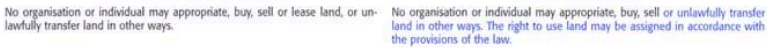


A Comparative Table of Constitutional Amendments since 1982 Article 11

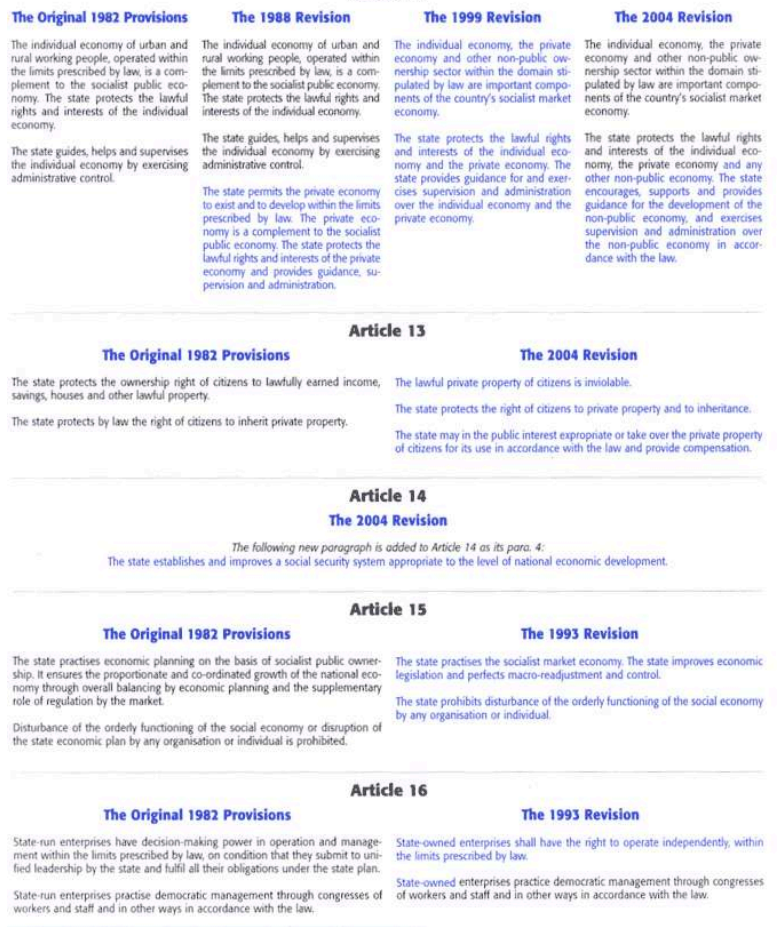




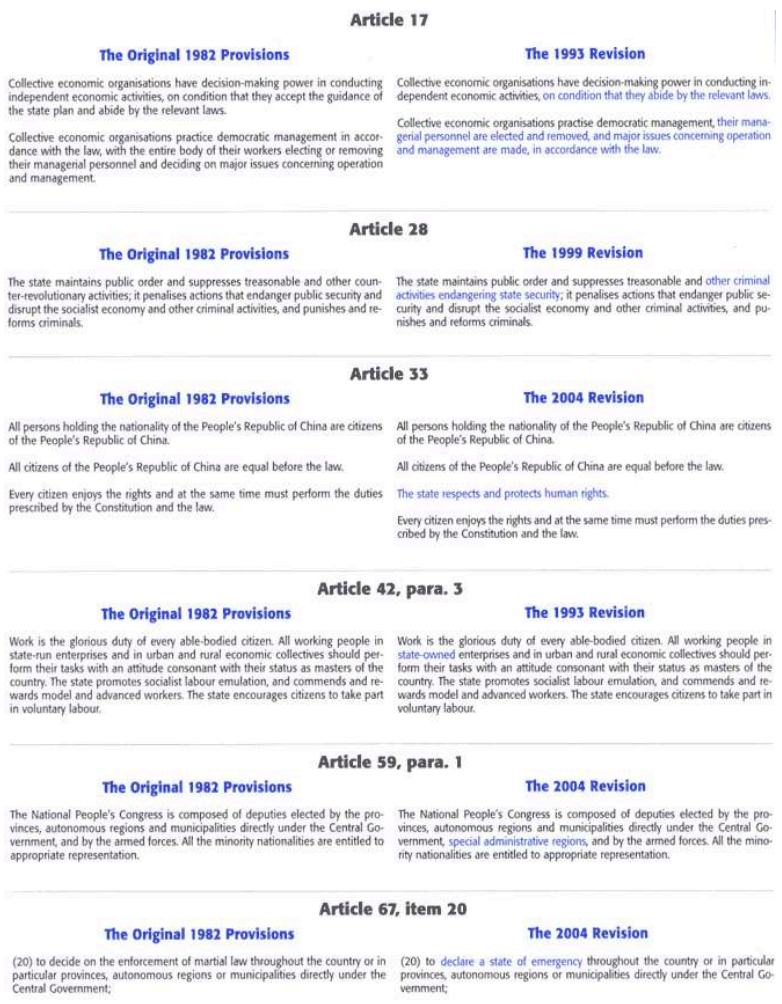

A Comparative Table of Constitutional Amendments since 1982

\begin{tabular}{|c|c|c|}
\hline \multicolumn{3}{|c|}{ Article 80} \\
\hline The Original 1982 Provisi & sions & The 2004 Revision \\
\hline The President of the People's Republic of China, ...pro & nodaims martial law; $\ldots$ & The President of the People's Republic of China, ... dedares a state of emergency. \\
\hline \multicolumn{3}{|c|}{ Article $\mathbf{8 1}$} \\
\hline \multicolumn{2}{|l|}{ The Original 1982 Provisions } & The 2004 Revision \\
\hline \multicolumn{2}{|c|}{$\begin{array}{l}\text { The President of the People's Republic of China receives toreign diphomatic re- } \\
\text { presentatives on behalf of the Proplés Repubbic of China; }\end{array}$} & $\begin{array}{l}\text { The President of the Peoplés Republic of China conducts state affaits and re- } \\
\text { ceive foreign diplamatic tepresentatives on behall of the People's Republic of } \\
\text { China; :. }\end{array}$ \\
\hline \multicolumn{3}{|c|}{ Article 89 , item 16} \\
\hline \multicolumn{2}{|c|}{ The Original 1982 Provisions } & The 2004 Revision \\
\hline \multicolumn{2}{|c|}{$\begin{array}{l}\text { (16) to decide on the enforcement of martial law in parts of provinces, auto- } \\
\text { nomous seg ions and municapalties directly under the Central Covernment, }\end{array}$} & $\begin{array}{l}\text { (16) to dedare a state of emerergen in parts of provinces, autonomous regions } \\
\text { and municipalities divectly under the Central Covenenent in accordance with } \\
\text { the law; }\end{array}$ \\
\hline \multicolumn{3}{|c|}{ Article 98} \\
\hline The Original 1982 Provisions & The 1993 Revision & The 2004 Revision \\
\hline 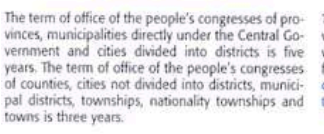 & \multicolumn{2}{|c|}{ 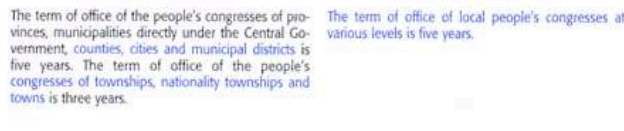 } \\
\hline \multicolumn{3}{|c|}{ Title of Chapter 4} \\
\hline \multicolumn{2}{|c|}{ The Original 1982 Provisions } & The 2004 Revision \\
\hline \multicolumn{2}{|c|}{ Chapter four - The National Flag the National Emblem and the Capital } & $\begin{array}{l}\text { Chapter Fout - The National Flag the National Anthem, the National Emblem and } \\
\text { the Capital }\end{array}$ \\
\hline \multicolumn{3}{|c|}{ Article 136} \\
\hline \multicolumn{2}{|c|}{ The Original 1982 Provisions } & The 2004 Revision \\
\hline \multicolumn{2}{|c|}{ The national fiag of the People's Republic of China is a red flag with five stars. } & 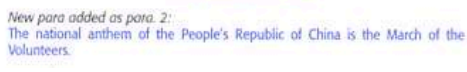 \\
\hline
\end{tabular}




\section{NOTES}

1. It should be pointed out that, while much attention has been focused on the revision of the state Constitution by the NPC, the Constitution of the Chinese People's Political Consultative Conference (CPPCC), which was holding its parallel meeting at approximately the same time, was also revised along similar lines. The Amendments to the Constitution of the CPPCC were adopted at its closing session on March 12th 2004, with 1,839 votes in favour, 52 against and 113 abstentions. See Xinhua website, March 12th 2004.

2. See Renmin ribao (People's Daily) editorial, March 15th 2004.

3. Each revision coincides with the completion of the five-year term of the Party Congress (1982-1987, 1987-1992, 1992-1997, 1997-2002, 2002-2007) and the beginning of a new five-year term of the National People's Congress (1983-1988, 1988-1993, 1993-1998, 1998-2003, 2003-2008).

4. See Jiang Bikun, et al. (ed.), Xianfa xue (Constitutional Law), Peking, Zhongguo zhengfa daxue chubanshe, 1993, p. 5.

5. The Constitutional Amendment Bill of the PRC was adopted on March 14th 2004 with 2,863 votes in favour, 10 against and 17 abstentions and was immediately promulgated by the NPC. The amendments and the revised Constitution was published in all major newspapers in China on March 15th 2004.

6. See Jianfu Chen, "The Revision of the Constitution in the PRC-Conceptual Evolution of 'Socialism with Chinese Characteristics"', China Perspectives, No. 24, July-August 1999, pp. 66-79.

7. Ibid.

8. The "Four Fundamental Principles" are vaguely stated in para. 7 of the Preamble of the 1982 Constitution which provides that "The Chinese people of all nationalities will continue to be led by the Communist Party of China, guided by Marxism-Leninism and Mao Zedong Thought, adhere to the people's democratic dictatorship and follow the socialist road".

9. Pu Zengyuan, "The Movement for Constitutionalism and Constitutions in TwentiethCentury China", in Alice E-S. Tay and Conita Leung (eds.), Constitution-making and Restructuring in the Present and Former Communist World, special issue of the Bulletin of Australian Society of Legal Philosophy, Vol. 17, Nos. 58/59, 1992, p. 162, p. 169. See also Jiang Bikun, Xianfa xue, op. cit., pp. 3-4; and Zhang Youyu, "Jiaqiang xianfa lilun yanjiu" (Strengthening the Research on Constitutional Theories), in Zhongguo faxue hui (Chinese Society of Legal Science) (ed), Xianfa lunwen xuan (A Selection of Papers on the Constitution), Peking, Qunzhong chubanshe, 1983, p. 2.

10. Thus, according to Chinese scholars, Party policy is translated, through legal procedure, into state will. See Liu Zheng, "Wei jianshe you Zhongguo tese de shehuizhuyi tigong youli de xianfa baozhang" (Further Constitutional Protection for the Construction of Socialism with Chinese Characteristics), Zhongguo faxue (Legal Science in China), No. 2, 1993, p. 6. A full text of these "suggestions" can be found in Fazhi ribao (Legal Daily), February 16th 1993, p. 1. The Constitutional Amendment was adopted by the First Session of the Eighth NPC on March 29th 1993. 
11. See "Guangyu Zhonghua renmin gongheguo xianfa xiuzheng an de shuoming" (Explanations on the Constitutional Amendment Bill), presented to the Ninth NPC by Tian Jiyun on March 9th 1999, in Renmin ribao, March 9th 1999, p. 1.

12. See Political Report on the Fifteenth Party Congress, delivered by Jiang Zemin on September 12th 1997. An English translation of the Report appears in http:// www.chinadaily.net/cndy/history/15/fulltext.html.

13. The Proposal was published in full in the Renmin ribao, January 31st 1999, p. 1.

14. Although there were 21 votes against the adoption and 24 abstentions, there were no dissenting views published in the media in China.

15. One amendment does not sit well with the above categories; that is, the replacement of the term "counter-revolutionary activities" with the term "criminal activities jeopardising the state security" in Article 28-a change that occurred earlier in 1997 when the Criminal Law of the PRC was comprehensively revised. For a detailed discussion of the 1999 constitutional revision, see Jianfu Chen, op. cit.

16. Jiang passed his positions as Party Secretary-General and the President of the State to Hu Jintao in 2002 (at the Party Congress) and 2003 (at the NPC) respectively.

However, Jiang continues to hold the Chairmanship of the Central Military Commission. 17. See "Explanation on the Draft Bill of the Constitutional Amendments", presented to the Second Plenary Session of the Tenth National People's Congress by Wang Zhaoguo, March 8th 2004. The full text was published in the Renmin ribao, March 8th 2004, http:// www.peopledaily.com.cn.

18. Ibid.

19. Renmin ribao, August 12th 2003, p. 1 .

20. Ibid.

21. Thus, the Caijing Weekly (www.Caijing.com.cn) reported, on June 20th 2003, a meeting between $\mathrm{Wu}$ Bangguo as head of the Constitutional Group with several prominent Chinese economists and jurists, at which he solicited opinions from these scholars on the pending constitutional revision. Agence France Presse, based on a Caijing Weekly report, then reported, on June 23rd 2003, the "secret" establishment of a constitutional revision group.

22. For an excellent overview of academic studies on constitutional revision that have emerged since 2001, see Zeng Ping, "Xianfa xiugai wenti yanjiu zongshu" (A Summary of Research on Issues Relating to Constitutional Revision), in Renmin ribao website, http://www.peopledaily.com.cn/GB/14576/14841/2084188.htm.

23. A detailed summary of views expressed at the Qingdao conference is available from www.usc.cuhk.edu.hk/wk_wzdetails.asp?id=2550.

24. A detailed summary of views expressed at Shanghai conference is available from www.usc.cuhk.edu.hk/wk_wzdetails.asp?id=2368.

25. See John Pomfret, "China Orders Halt to Debate on Reforms", Washington Post, August 27th 2003, p. 01. Although rumours had it that there was a written document to the effect that further debate on constitutional and political reform was banned, interviews with Chinese scholars seem to suggest that only an oral instruction ( $d a$ zhaohu) was circulated to this effect. Since academic papers continued to appear in journals and newspapers and on websites, it seems that it is more likely that the instruction was in an oral form with limited effect.

26. See "Explanation on the Draft Bill of the Constitutional Amendments", op. cit. 27. Ibid. 
28. For a detailed discussion on the evolution of the guiding constitutional principles, including the introduction of the Four Fundamental Principles and Deng Xiaoping Theory, see Jianfu Chen, op. cit.

29. Interestingly, the most comprehensive statement on the Three Represents is contained in the much anticipated and widely publicised first major speech by the new Party Secretary-General, Hu Jintao on commemorating the 82nd anniversary of the founding of the CPC on July 1st 2003. The full speech was published in the Renmin ribao, July 2nd 2003.

30. The phrase was earlier added to Article 5 of the Constitution in 1999. See Jianfu Chen, op. cit.

31. An English version of the Party Constitution is available in the China Daily, December 6th 2002. A Chinese text of the Party Constitution is available in the Renmin ribao, November 19th 2002. This English translation has been modified according to the original Chinese texts.

32. See paragraph 13 of the revised Party Constitution.

33. Now sometimes called the "Five Fundamental Principles". See Jianfu Chen, op. cit..

34. See paragraph 1 of the revised Party Constitution.

35. He Weifang, "Zhongguo fazhi jianshe de kunjing yu chulu" (Difficulties in Establishing Rule of Law and Solutions), published in http://www.law-thinker.com/ details.asp?id=476

36. Here I am not endorsing the practice of imposing a Party ideology upon the will of the people, however well the ideology is formulated. It certainly has little foundation in asserting that it is the desire or the aspiration of the people to incorporate the "Three Represents" in the Constitution, as some deputies to the NPC would like us to believe. 37. See amendment to paragraph 10 of the Preamble.

38. See Jianfu Chen, From Administrative Authorisation to Private Law, Bordrecht, Boston, London, Martinus Nijhoff Publishers, 1995, Ch. 3.

39. It is a quiet change as it has attracted little discussion in the Chinese media. Indeed, the "Explanation on the Draft Bill of the Constitutional Amendments" (op. cit.) does not explain the reasons for the change at all.

40. A new insert in Article 33 of the Constitution.

41. See Ronald C. Keith, China's Struggle for the Rule of Law, New York, St. Martin's Press, 1994, pp. 66-67; "Recent Human Rights Studies in the PRC", being Annex II to the Report of the Second Australian Human Rights Delegation to China 8-20 November 1992, Canberra, AGPS, 1993, pp. 99-100. See further discussions in Jianfu Chen, Chinese Law: Towards an Understanding of Chinese Law, Its Nature and Development, The Hague, London, Boston, Kluwer Law International, 1999, pp. 90-93.

42. See Keith, op. cit., pp. 66-72. The white paper was published in several languages. For an English version, see Beijing Review, November 4th-10th, 1991.

43. China signed the International Covenant on Political and Civil Rights on October 5th 1998, and the International Covenant on Economic, Social and Cultural Rights on October 27th 1997, with the latter having already been ratified by the Standing Committee of the NPC on February 28th 2001 and the likelihood of ratification of the former in the future.

44. See Jianfu Chen, Chinese Law: Towards an Understanding of Chinese Law, Its Nature and Development, op. cit., p. 93.

45. Zhang Youyu, "Strengthening the Research on Constitutional theories", in Chinese Society of Legal Science, op. cit, pp. 8-9; Gu Angran, Shehui zhuyi fazhi jianshe he lifa 
gongzuo (The Construction of a Socialist Legal System and Legislative Work), Peking, Zhongguo zhengfa daxue chubanshe, 1989, pp. 92-93; Sun Yamin, "Shehui zhuyi minzhu yu fazhi de xin fazhan" (The New Developments in Socialist Democracy and Socialist Legality), in Zhang Youyu (ed.), Xianfa lunwen ji (A Collection of Papers on the Constitution) (Supplementary Volume), Peking, Qunzhong chubanshe, 1982, p. 19; and $\mathrm{Wu}$ Jie and Xu Xiuyi, "Lun falu mianqian renren pingdeng yuanze" (On the Principle of Equality before the Law), in Chinese Society of Legal Science, op. cit., pp. 134-141. 46. For further discussion on the changes of wording in relation to equality before the law under the various Chinese constitutions, see Jianfu Chen, Chinese Law: Towards an Understanding of Chinese Law, Its Nature and Development, op. cit., p.92.

47. For instance, on the commemorating of the twentieth anniversary of the promulgation of the Constitution on December 4th 2002, Hu Jintao emphasised that "[I]t is desirable to promote the Constitution extensively in society so that it is known to every household and penetrates to the people's heart, which will lead the broad masses of people to the notion that the Constitution is not only a norm every citizen should observe in behaviour, but also a legal weapon with which they can safeguard their citizens' rights." An English translation of his speech is available from 2 (3) 2003 Human Rights, pp. 1-5. (Human Rights is published by the China Society for Human Rights Studies, Peking).

48. "Top legislators consider amending constitution again", id. In mid-March 2004, for the first time, Chinese media reported that some 10,000 people were sentenced to immediate execution each year, not including people sentenced to death with a twoyear suspension. See " 41 deputies suggested that the Supreme People's Court should recentralise the approval power over the death penalty", originally published in the Zhongguo qingnian bao (China Youth Daily), and re-published in the Renmin ribao, March 16th 2004 Internet edition viewed at: http://www.people.com.cn/GB/shehui/ $1060 / 2388561 . h t m l$. In this context, any positive change in the state value system is potentially life-saving.

49. Jianfu Chen, Chinese Law: Towards an Understanding of Chinese Law, Its Nature and Development, op. cit., pp. 290-291.

50. Article 2 of the Provisional Regulations of the PRC on Private Enterprises (1988). See further discussions in Jianfu Chen, ibid., pp. 291-292.

51. By early 1999, it accounted for $15 \%$ of GDP. See "Constitutional Amendments Propel China's Reform and Opening-up”, China Daily, March 17th 1999. By November 2003, there were some 2.97 million registered private businesses with a registered capital of more than US $\$ 40$ billion, and contributing half of China's economic growth. See "Private firms need support, understanding", China Daily, Internet edition, March 10th 2004, www.chinadaily.com.cn.

52. See 1999 amendment to Article 11.

53. As can be seen in the Appendix to this paper (the Comparative Table of Constitutional Amendments), disparities existed in the wording on the protection and control of the individual and private economies prior to the 1999 revision. The distinction of the two sectors, depending on whether private employment involves eight or more people, is artificial and arbitrary. Such a distinction is increasingly blurred in practice. See Jianfu Chen, From Administrative Authorisation to Private Law: A Comparative Perspective of the Developing Civil Law in the PRC, Dordrecht, Boston, London, Martinus Nijhoff Publishers, 1995, pp. 113-116. 
54. Article 7 of the Constitution still states that "[T] sector of the socialist economy under the ownership of the whole people is the leading force in the national economy. The state ensures the consolidation and growth of the state-owned economy". And indeed, in some important economic activities, such as obtaining bank loans, the state sectors continue to have priority.

55. For socialist conceptions of property, see Viktor Knapp, "Socialist Countries" and F.H. Lawson, “Comparative Conclusions” in Int'l.Enc.Comp.L., Vol. vi (Property and Trust), Ch. 2 (Structural Variations in Property Law), S.3 and S.8 respectively; John N. Hazard, Communists and Their Law: A Search for the Common Core of the Legal Systems of the Marxian Socialist States, Chicago, London, The University of Chicago Press, 1969, chapters 8 and 9; and Jianfu Chen, From Administrative Authorisation to Private Law: A Comparative Perspective of the Developing Civil Law in the PRC, op. cit., pp. 144-149. See also "Explanation on the Draft Bill of the Constitutional Amendments", op. cit., p. 18.

56. See revised Article 10 of the Constitution.

57. See Jianfu Chen, Chinese Law: Towards an Understanding of Chinese Law, Its Nature and Development, op. cit., Chapter 5.

58. In the last ten years or so, China has gradually established a social security structure, composed of retirement insurance, medical insurance, unemployment insurance, insurance for work-related injuries, and birth insurance, and covering a total population of some 100 million people. However, other than rudimentary medical, poverty and old pension insurance for rural populations in coastal regions, the social security system is yet to reach the rural population. See Press Conference given by the Minister for Labour and Social Security, March 11th 2004, Xinhuanet: www.xinhuanet.com/zhibo/20040309b/wz.htm.

59. See revised Article 14 of the Constitution.

60. See Article 67 (20), 80, and 89 (16) of the Constitution before the present revision.

61. Adopted by the Standing Committee of the NPC on March 1st 1996 and effective on the same date.

62. Under Article 8 of the Martial Law of the PRC (1996), martial law is to be enforced by police and armed police and, if necessary, the army may be called in to assist in its enforcement. Thus, martial law is not necessarily enforced by the army, but the experiences of 1989 have been to the contrary and thus left people with the impression that an order for martial law would inevitably be enforced by the army. See also "Constitutional amendment paves way for drafting emergency law", in http:// news.xinhuanet.com/english/2004-01/06/content_1333061.htm.

63. The SARS epidemic and other natural disasters are examples given by Wang in his explanation of the need for the revision so as to expand the scope that would be covered by the Constitution and the law. See "Explanation on the Draft Bill of the Constitutional Amendments", op. cit.

64. Other than the above "definition" of circumstances for which martial law may be imposed, the 1996 Martial Law only codifies the constitutional provisions without elaborating either the procedures or the criteria. A law on state emergencies is currently listed among the 76 laws that will be drafted during the Tenth NPC's five year term. See the Five-Year Legislative Plan, available at the Renmin ribao website: www.peopledaily.com.cn.

65. See revised Article 59 of the Constitution.

66. See revised Article 81 of the Constitution. 
67. See revised Article 98 of the Constitution.

68. The lyrics of the March of the Volunteers were written by the well-known poet Tian Han and the music composed by the well-loved composer Nie Er in 1935, in honour of those fighting the Japanese invasion in the 1930s. It was initially adopted by the Chinese People's Political Consultative Conference (CPPCC), in September 1949 as an interim national anthem. Tian Han was, however, denounced as a traitor during the Cultural Revolution, and for many years the March of the Volunteers was played as a national anthem without words. It was not until December 1982 that the NPC officially proclaimed it the national anthem.

69. See revised title of Chapter 4 and Article 136 of the Constitution.

70. Interestingly, two prominent professors invited to offer their opinions by the Constitutional Revision Group, Professors Jiang Ping and Wu Jinlian, unambiguously opposed the direct incorporation of the Three Represents, though they agreed that the "spirit" of the new thinking would be appropriate for incorporation in the amendment. See "Jiang Ping jiaoshou zai zhonggong zhongyang xiuxian xiaozu zhuanjiao zuotanhui de fayan" (Speech by Jiang Ping at the Expert Seminar Organised by the Constitutional Revision Group of the Central Committee of the CPC), and "Wu Jinlian jiaoshou zai zhonggong zhongyang xiuxian xiaozu zhuanjiao zuotanhui de fayan" (Speech by Wu Jinlian at the Expert Seminar Organised by the Constitutional Revision Group of the Central Committee of the CPC), in www.law-thinker.com.

71. See the Preamble of the Constitution of the PRC (1982). See also Gu Angran, Shehui zhuyi fazhi jianshi he lifa gongzuo, op. cit., p. 57; and Zhang Youyu, "Renzhen shiji de taolun" (To Discuss Seriously and Practically), in Zhang Youyu, Xianfa lunwen ji, op. cit., p. 5.

72. In 1954 when the first constitution of the PRC was adopted, Mao Zedong declared that "An organisation must have rules, and a state also must have rules; the Constitution is a set of general rules and is a fundamental charter [of the state]". See Chang Chun-chiao (one of the Gang of Four), "Report on the Revision of the Constitution (delivered at the First Session of the Fourth National Peoples Congress, 1975)", in Joseph En-pao Wang (ed.), Selected Legal Documents of the PRC, University Publications of America, 1976, p. 93. Despite the official repudiation of the Cultural Revolution and part of Mao Zedong Thought, Mao's idea of the constitution is still followed by the contemporary leadership and law-makers in the PRC. See Gu Angran, Shehui zhuyi fazhi jianshi he lifa gongzuo, op. cit., p. 50.

73. The Chinese leadership has never denied the fact that the Party has a heavy-handed involvement and exercises strong control over the making and revision of constitutions of the PRC. See Gu Angran, ibid., pp. 53-60. Even though Article 64 of the 1982 Constitution requires that "amendments to the Constitution are to be proposed by the Standing Committee of the National People's Congress or by more than one-fifth of the deputies to the NPC and adopted by a majority vote of more than two-thirds of all the deputies to the Congress", all recent amendments to the Constitution were initiated and drafted by the Party despite recent calls for the separation of the Party and the state. Indeed, it is now suggested that one of the unwritten constitutional conventions (guanli) in China is that major issues concerning the state, such as the revision of the Constitution, are to be initiated by the Party, though nominally decided by the Legislature. See Jiang Bikun, op. cit., p. 38.

74. Indeed, Chinese scholars have identified many constitutional issues that need urgent solution if the Constitution is to be effective in fulfilling its intended functions. 
See views expressed at Qingdao and Shanghai seminars on constitutional reform, supra notes 23 and 24; Zeng Ping, op. cit. See also special collections of articles on constitutional revision: Zhengfa luntan (Journal of the China University of Political Science and Law), No. 2, 2003; Zhengzhi yu falü (Political Science and Law), No. 3, 2003; Zhongguo faxue (China Legal Science), No. 3, 2003; and Zhongwai faxue (Peking University Law Journal), No. 5, 2003.

75. In a recent Internet survey conducted by the Xinhua News Agency, anti-corruption was the top concern among the people participating in the web survey conducted before and during the Second Session of the Tenth NPC. See www.xinhuanet.com. A year ago, the People's Daily conducted a similar survey, which received responses from more than 200,000 people, and indicated that anti-corruption and the establishment of checks and balances were nominated as the top issue that people expected the Tenth National People's Congress (NPC) (2003-8) to address. See "Top ten issues selected by netizens for the NPC to address", Renmin ribao, Internet edition, February 26th 2003. Also according to Xinhua, as of October 2003 there were no fewer than 4,000 corrupt officials who had fled China, with more than US $\$ 5$ billion having been stolen by them and transferred overseas and, in the last three years alone, no less than US $\$ 53$ billion has been illegally transferred overseas through corruption.

76. Despite the controversy and major debates in legal circles, the original judgment has not been published. There were however many media reports on the case and its decision: "Faguan pan difangxing fagui wu xiao: weifa huoshi hufa?" (Judge holds local regulation invalid: a violation of law or a support for law?), Nanfang zhoumo, Internet edition (http://www.nanfandaily.com.cn/zm/20031120/xw/fz/200311200861.asp), November 20th 2003; "Judge sows seeds of lawmaking dispute", China Daily, Internet edition (http://www.chinadaily.com.cn/en/doc/2003-11/24/content_283973.htm), November 24th 2003; "Lawyers request the National Congress to undertake legislative review over 'Luoyang Seed Case”', Phoenix TV, Internet edition viewed at: (http:// www.phoenixtv.com/home/news/society/200311/21/151034.html). November 21st 2003; and articles collected in http://www.law-thinker.com. After the intervention by the provincial legislature, the Luoyang Intermediary Court Party Committee then decided to remove Judge Zhao from the position of Deputy Head of the Economic Chamber. It also removed Judge Li from Presiding Judge and dismissed her from the position of assistant judge, both pending formal legal procedures with the Standing Committee of the Luoyang People's Congress. However, according to follow-up reports in February 2004, the decisions to dismiss the judges were never actually submitted to the Standing Committee of the Luoyang People's Congress for deliberation and approval, apparently because of the controversy, and Judge Li, on sick leave since then, was notified to resume her work in the court. See "Dui falü chongtu buke "lengchuli" (Conflict of law shall not be dealt with by 'cool handling'), Nanfang dushi bao, Internet edition (http://www.nanfandaily.com.cn/southnews/spqy/zy/2000402070066.asp, February 7th 2004, and "Henan Li Huijuan shijian zai qi polan" (Further controversy concerning Li Huijuan Affair in Henan), Zhongguo qingnianbao, Internet edition (http:// www.cyol.com/zqb/gb/zqb/2004-02/06/content_813990.htm, February 6th 2004. 77. For a summary of the case, see Nanfang zhoumo, Internet edition, 17 August 2001, and Renmin ribao, Internet edition, 5 September 2001. The Supreme People's Court reply was issued on 24 July 2001, as Interpretation [2001] No. 25.

78. For detailed academic analysis of the two cases, see Shen Kui, "Xianfa tongzhi shidai de kaishi? - Xianfa diyi an quanyi" (The Beginning of the Age of Constitutionalism - 
Questions regarding the First Constitutional Case), published in the Peking University Law website: www.law-dimension.com/details.asp?id=758; and Li Huawei, "Dalu weixian shencha zhidu de shuguang?" (A New Light in Constitutional Review in Mainland China?), available from the China Constitutionalism web: www.calaw.cn/ include/shownews.asp?newsid=2001.

79. The survey was conducted by Shangguan Piliang in collaboration with many doctoral and other students in eastern coastal cities in November - December 2002. Altogether, 1001 questionnaires were distributed to the public, and collected. A full report of the survey is published on the website of the Law Institute of the Chinese Academy of Social Sciences: www.iolaw.org.cn/shownes.asp?id=3813.

80. In 2003, a university graduate named Sun Zhigang was detained in a Southern city in Guangdong Province under the then State Council Measures on Detention and Repatriation and was apparently beaten to death. Several scholars then petitioned the Standing Committee of the NPC to start a constitutional review of the Measure. However, the Measure was quickly repealed by the State Council before any Standing Committee procedure was actually activated. A summary of the petition was published in www.chinalaw.gov.cn. Equally, in relation to the Seeds case, many scholars have urged the government to consider the establishment of practical constitutional mechanisms.

81. See e.g., Shang Xiaoyu, "Xiugai xianfa ying zhen zhi you zhen" (Doubly cautious about constitutional revision), Jiancha ribao (Procuratorial Daily), March 10th 2004, Internet edition, www.jcrb.com/n1/jcrb81/ca50485.htm.

82. Indeed, barely two weeks after the adoption of the present revision, an elder resident in Peking had already used the revised constitutional provisions on the protection of private property to stop the demolition of his old house that was built more than a hundred years ago in Peking. See Xinhuanet: http://news.xinhuanet.com/ comments/2004-04/07/content_1405016.htm. These are clearly admirable actions on the part of the ordinary citizens that would give life to the Constitution on paper. 83. Almost immediately after the revision of the Constitution, a group of 30 scholars have already produced some 18 suggestions for constitutional reforms to implement human rights protection as now enshrined in the Constitution. See He Weifang, Ji Weidong et al., "Wanshan woguo xianfa renquan baohu tiaokuan de jianyi" (Suggestions for the I improvement of the Constitutional Protection of Human Rights in Our Country), available at http://www.law-thinker.com/details.asp?id=2078. Even though these suggestions are unlikely to be implemented any time soon by the government, such academic activities keep constitutional reform alive on the agenda of national debate and discussion. 